\title{
APLIKASI STRATEGI PREVIEW, QUESTION, READ, REFLECT, RECITE AND REVIEW (PQ4R) DALAM MENINGKATKAN KEMAMPUAN KOMUNIKASI MATEMATIKA DAN SELF-REGULATED LEARNING
}

\author{
NAILUL AUTHARY \\ ${ }^{1}$ Universitas Muhammadiyah Aceh, Jalan Muhammadiyah No.91, Banda Aceh \\ ${ }^{1}$ nailulautharympd@gmail.com
}

\begin{abstract}
Abstrak
Komunikasi yang efektif sangat penting dalam pembejaran. Salah satu keuntungan komunikasi matematika yang efektif antara guru dan peserta didik serta antara peserta didik dan peserta didik adalah tercapainya tujuan pembelajaran. Pada sisi berbeda, pembelajaran tidak akan maksimal jika hanya dilaksanakan di kelas saja dengan waktu yang sangat terbatas. Kemampuan self regulated learning menjadi kemampuan lain yang dibutuhkan oleh seorang peserta didik. Untuk itu strategi preview, question, read, reflect, recite dan review (PQ4R) dapat digunakan untuk meningkatkan kemampuan tersebut. Keadaan ini yang menjadi titik incar dalam artikel ini. Hasil kajian diperoleh PQ4R berperan penting dalam belajar matematika. Sehingga terjadi komunikasi yang efektif antara siswa dan guru dengan saling berinteraksi dan berkomunikasi mengenai materi matematika yang sedang dipelajari.
\end{abstract}

Kata Kunci: PQ4R, Komunikasi Matematika, Self-Regulated Learning

\begin{abstract}
Effective communication is essential in learning. One of the advantages of effective mathematics communication between teachers and learners as well as between learners and learners is the achievement of learning objectives. On the other hand, learning will not be maximal if it is only implemented in the classroom with very limited time. The ability of selfregulated learning to be other skills required by a learner. The strategy preview, question, read, reflect, recite and review (PQ4R) can be used to improve the ability. This situation is the point in this article. The results of the study obtained PQ4R plays an important role in learning mathematics. So that there is an effective communication between students and teachers with each other interact and communicate about the math material being studied.
\end{abstract}

Keywords: PQ4R, Mathematical Communication, Self-Regulated Learning

\section{Pendahuluan}

Permendiknas No 22 tentang Standar Isi Mata Pelajaran Matematika menyatakan bahwa pelajaran matematika SMA bertujuan agar para siswa SMA: (1) memiliki pengetahuan matematika (konsep, keterkaitan antarkonsep, dan algoritm; (2) menggunakan penalaran; (3) memecahkan masalah; (4) mengomunikasikan gagasan dengan simbol, tabel, diagram, atau media lain untuk memperjelas keadaan atau masalah; dan (5) memiliki sikap menghargai 
kegunaan matematika. Standar matematika sekolah meliputi standar isi atau materi dan standar proses. Standar proses meliputi pemecahan masalah (problem solving), penalaran (reasoning), dan komunikasi (communication).

Salah satu hal yang sangat umum dalam pembelajaran matematika yaitu komunikasi. Menurut Baroody (1993) ada dua alasan mengapa komunikasi matematika sangat penting dikembangkan pada siswa. Pertama, mathematics as languange, ini berarti matematika tidak hanya sebagai alat untuk membantu berpikir, menemukan pola, menyelesaikan masalah atau menentukan kesimpulan, tetapi matematika juga merupakan suatu alat yang sangat berharga untuk menyampaikan ide secara jelas, tepat dan ringkas. Kedua, mathematics learning as social activity, ini berarti terdapat aktivitas sosial dalam pembelajaran matematika, seperti interaksi antar siswa dan juga interaksi antara guru dan siswa. Hal ini menjadi bagian penting untuk mengembangkan potensi matematika siswa.

Sebaliknya, tanpa adanya komunikasi matematika yang baik perkembangan kognitif siswa akan terhambat dengan tidak sampainya pesan. Seperti penyampaian ide, menerima pesan, menulis, mendengar dan berdiskusi. Unsur pesan yang diharapkan dapat dipahami siswa melalui komunikasi matematika berupa konsep-konsep matematika.

Selain aspek kognitif, hal yang juga menjadi fokus perhatian yaitu aspek afektif. Aspek afektif mempunyai peranan penting dalam kesuksesan pembelajaran matematika. Hal ini sejalan dengan undang-undang Sistem Pendidikan Nasional Pasal 1, yaitu:

Pendidikan adalah usaha sadar dan terencana untuk mewujudkan suasana belajar agar peserta didik secara aktif mengembangkan potensi dirinya untuk memiliki kekuatan spiritual keagamaan, pengendalian diri, kepribadian, kecerdasan, akhlak mulia serta keterampilan yang diperlukan dirinya, masyarakat, bangsa dan negara.

Untuk mengembangkan salah satu potensi yang dimiliki siswa dalam pengendalian diri, salah satunya dapat dengan mengembangkan self-regulated learning. Kemampuan selfregulated learning merupakan kemampuan siswa untuk memiliki kemandirian belajar serta kemampuan untuk mengatur motivasinya sendiri. Tidak hanya motivator eksternal tetapi juga motivator internal serta mampu menyelesaikan tugas jangka panjang.

Untuk dapat melakukan semua tugas dibutuhkan pengetahuan mengenai konsep-konsep yang terdapat di dalam buku teks matematika tidak dapat dipindahkan secara langsung kepada siswa. Siswa harus melakukan aktivitas untuk membangun pengetahuan pengetahuan sendiri dengan membaca. Salah satu strategi membaca yang diduga dapat mengembangkan keterampilan metakognitif adalah Preview, Question, Read, Reflect, Recite, Review (PQ4R) yang dikembangkan oleh Arends (1997) dan Slavin (2000). 
Strategi ini digunakan untuk membantu siswa mengingat kembali apa yang telah dibaca. Aktivitas membaca tidak dapat digantikan dengan strategi yang lain. Siswa dapat berkomunikasi antara satu sama lain dengan membaca. Sebagai proses interaksi, membaca akan mempengaruhi pengetahuan dan strategi membaca sangat berhubungan dengan selfregulated learning.

Berdasarkan penjelasan latar belakang masalah di atas maka yang menjadi titik incar makalah ini adalah: pertama, apakah dengan aplikasi Strategi Preview, Question, Read, Reflect, Recite dan Review (PQ4R) dapat meningkatkan kemampuan komunikasi matematika dan Self-Regulated Learning lebih baik dibandingkan dengan pembelajaran konvensional ditinjau dari keseluruhan siswa?,

kedua, apakah dengan aplikasi Strategi Preview, Question, Read, Reflect, Recite dan Review (PQ4R) dapat meningkatkan kemampuan komunikasi matematika dan Self-Regulated Learning lebih baik dibandingkan dengan pembelajaran konvensional ditinjau dari tingkat kemampuan siswa (a) tinggi, (b) sedang, (c) rendah. klasifikasi kemampuan siswa di bedakan menjadi 3, yaitu : (1) Siswa dengan kemampuan pembuktian tinggi jika siswa tersebut memperoleh nilai lebih dari atau sama dengan 70 dan kurang dari sama dengan 100, (2) Siswa dengan kemampuan pembuktian sedang jika siswa tersebut memperoleh nilai lebih dari atau sama dengan 55 dan kurang dari 70, (3) Siswa dengan kemampuan pembuktian rendah jika siswa tersebut memperoleh nilai kurang dari atau sama dengan 0 dan kurang dari 55

Adapun tujuan akhir dari penulisan ini adalah untuk mengetahui aplikasi Strategi Preview, Question, Read, Reflect, Recite dan Review (PQ4R) dalam Meningkatkan Kemampuan Komunikasi Matematika dan Self-Regulated Learning

Untuk menghindari perbedaan penafsiran beberapa istilah dalam makalah ini di rasa sangat perlu untuk memberikan batasan istilah agar tidak menimbulkan berbagai penafsiran sebagai berikut:

\section{Komunikasi Matematika}

Dalam NCTM (2000) dijelaskan bahwa komunikasi adalah suatu bagian essential dari matematika dan pendidikan matematika dengan demikian dapat tersampaikannya ide-ide dari guru dan media lainnya.

Menurut Baroody (1993) komunikasi matematika adalah kemampuan yang meliputi merepresentasi, mendengar, membaca, diskusi dan menulis. Sedangkan definisi komunikasi matematika yang penulis maksud adalah kemampuan siswa menerima dan menyampaikan ideidenya dengan cara merepresentasi, mendengar, membaca, diskusi dan menulis. 


\section{Self-Regulated Learning}

Menurut Kerlin, B.A (1992), self regulated learning adalah suatu usaha yang mendalam dengan memanfaatkan sumber daya dan jaringan yang ada, memonitor dan meningkatkan proses yang mendalam. Pintrich (dalam Boekaerts, et al.,(2000) menyatakan bahwa self regulated learning adalah suatu proses konstruktif ketika siswa menetapkan tujuan belajar sekaligus mencoba memantau, mengatur dan mengendalikan pengamatan, motivasi serta perilakunya yang dibatasi oleh tujuan belajar dan lingkungan.

Sedangkan pengertian strategi self regulated learning yang penulis maksud adalah kemampuan siswa dalam merencanakan dan memonitor proses kognitif dan afektif yang melibatkan keberhasilan dalam menyelesaikan tugas-tugas matematika.

\section{Preview, Question, Read, Reflect, Review (PQ4R)}

Menurut Thomas dan Robinson (1999), Strategi Preview, Question, Read, Reflect, Review (PQ4R) adalah salah satu strategi belajar yang paling dikenal untuk membantu siswa dalam memahami dan mengingat materi yang mereka baca. Preview, Question, Read, Reflect, Review (PQ4R) yang penulis maksud adalah strategi belajar siswa dalam memahami dan mengingat materi matematika yang telah mereka baca.

Manfaat dari penelitian ini adalah:

a. Dapat menambah khazanah ilmu pengetahuan khususnya dalam pembelajaran matematika.

b. Dapat menambah pengetahuan bagi pembaca terutama guru bidang studi matematika.

\section{Hasil dan Pembahasan}

\section{Komunikasi Matematika}

Hiebert dan Carpenter (1992) mengatakan bahwa pemahaman merupakan faktor fundamental dalam proses pembelajaran, sehingga setiap model pembelajaran harus menyertakan hal pokok dari pemahaman. Dalam proses pembelajaran akan selalu terjadi peristiwa interaksi agar dapat membangun pemahaman. Proses interaksi ini merupakan suatu peristiwa saling berhubungan atau komunikasi antara guru sebagai pemberi pesan yang memiliki sejumlah unsur dan pesan yang ingin disampaikan kepada siswa sebagai penerima pesan.

Konteks pembelajaran matematika yang berorientasi pada siswa, pesan tidak terbatas pada guru saja melainkan dapat dilakukan oleh siswa maupun media lain, sedangkan unsur- 
unsur pesan yang dimaksud adalah konsep-konsep matematika. Cara menyampaikan pesan dapat dilakukan baik melaui lisan maupun tulisan.

NCTM (2000), dijelaskan bahwa komunikasi adalah suatu bagian esential dari matematika dan pendidikan matematika. Menurut pendapat ini menunjukkan bahwa pentingnya komunikasi dalam pembelajaran matematika. Melalui komunikasi, siswa dapat menyampaikan ide-idenya kepada guru dan kepada siswa yang lain. Siswa yang telah memiliki pemahaman matematika sebaiknya juga dapat mengkomunikasikannya, agar pemahaman dapat dipahami pula oleh orang lainnya untuk meningkatkan pemahaman matematikanya.

Ketika siswa berpikir, merespon, berdiskusi, mengelaborasi, menulis, membaca, mendengarkan, dan menemukan konsep-konsep matematika, mereka mempunyai berbagai keuntungan, yaitu berkomunikasi untuk belajar matematika dan belajar untuk berkomunikasi secara matematik (NCTM, 2000). Hal demikian dapat diartikan bahwa proses komunikasi yang baik memungkinkan siswa untuk membangun pengetahuan matematikanya.

Selanjutnya Sumarmo (2000) mengatakan bahwa kemampuan komunikasi matematika meliputi kemampuan: (1) menghubungkan benda nyata, gambar, dan diagram kedalam ide matematis; (2) menjelaskan ide, situasi dan relasi matematis secara lisan maupun tulisan dengan benda nyata, gambar, grafik dan aljabar; (3) menyatakan peristiwa sehari-hari dalam bahasa atau simbol matematika; (4) mendengarkan, berdiskusi, dan menulis tentang matematika;(5) membaca dengan pemahaman atau presentasi matematika tertulis; (6) membuat konjektur, menyusun argumen, merumuskan definisi dan generalisasi; (7) menjelaskan dan membuat pertanyaan tentang matematika yang dipelajari.

Menurut Baroody (1993), ada lima aspek komunikasi matematika, yaitu merepresentasi (representing), mendengar (listening), membaca (reading), diskusi (discussing) dan menulis (writing). Kelima aspek ini dapat dikembangkan menjadi tahap-tahap berlangsungnya komunikasi dalam pembelajaran matematika. Untuk menilai kelima aspek ini telah terpenuhi pada siswa dapat dilakukan dengan beberapa cara. Menurut Cai, Lane, dan Jacabscin (2000), untuk mengungkapkan kemampuan komunikasi matematika dapat dilakukan dengan cara diskusi dan mengerjakan berbagai bentuk soal, baik pilihan ganda maupun uraian.

Berikut contoh-contoh pertanyaan yang dapat diajukan kepada siswa.

1. Membantu siswa bekerja sama agar memiliki sense matematika, yaitu dengan mengajukan pertanyaan sebagai berikut.

a. Apakah yang orang lain pikirkan tentang yang kamu katakan?

b. Apakah kamu setuju? Tidak setuju? 
c. Apakah setiap orang mempunyai jawaban yang sama tetapi mempunyai cara berbeda untuk menjelaskannya?

d. Apakah kamu memahami apa yang mereka katakan?

2. Membantu siswa menyadari benar tidaknya suatu ide matematika, yaitu dengan mengajukan seperti berikut.
a. Mengapa kamu berpikir seperti itu?
b. Mengapa hal itu benar?
c. Bagaimana kamu menyimpulkan hal itu?
d. Dapatkah kamu membuat sebuah model untuk menunjukkan hal itu?

3. Membantu siswa mengembangkan penalaran, yaitu dengan mengajukan pertanyaan sebagai berikut.

a. Apakah hal itu selalu berlaku untuk kondisi lain?

b. Apakah hal itu benar untuk semua kasus?

c. Bagaimana kamu membuktikan hal itu?

d. Asumsi-asumsi apakah yang digunakan?

4. Membantu siswa membuat dugaan, penemuan, dan penyelesaian masalah, yaitu dengan mengajukan pertanyaan sebagai berikut.

a. Apa yang terjadi jika ...? Bagaimana jika tidak?

b. Dapatkah kamu melihat polanya?

c. Dapatkah kamu mempredisksi pola berikutnya?

d. Apakah persamaan dan perbedaan metode penyelesaianmu dengan temanmu?

5. Membantu siswa menghubungkan ide-de matematika dan aplikasinya, yaitu dengan mengajukan pertanyaan sebagai berikut.

a. Apakah hubungannya dengan konsep lain?

b. Ide-ide matematika apakah yang harus dipelajari sebelum digunakan untuk menyelesaikan masalah?

c. Apakah kamu pernah menyelesaikan masalah seperti ini sebelumnya?

d. Dapatkah kamu memberikan sebuah contoh tentang ...

Uraian terdahulu menjelaskan mengenai pengembangan kemampuan komunikasi dalam pembelajaran matematika. Di sisi lain, proses komunikasi yang terjalin dengan baik dapat membantu siswa membangun pemahamannya terhadap ide-ide matematika dan membuatnya menjadi lebih mudah dipahami. Ketika siswa ditantang untuk berpikir mengenai matematika dan mengkomunikasikannya kepada orang/siswa lain, secara lisan maupun tertulis, secara tidak langsung mereka dituntut untuk membuat ide-ide matematika itu lebih terstrukur dan menyakinkan, sehingga ide-ide itu menjadi lebih mudah 
dipahami, khususnya oleh diri mereka sendiri. Dengan demikian, proses komunikasi akan bermanfaat bagi siswa untuk meningkatkan pemahamannya mengenai konsep-konsep matematika.

Pembelajaran matematika perlu dirancang sedemikian sehingga dapat menstimulasi siswa untuk berkomunikasi dengan baik. Proses komunikasi yang baik ini diharapkan dapat menstimulasi siswa untuk mengembangkan berbagai ide-ide matematika atau membangun pengetahuannya. Hal demikian tidak akan terjadi apabila dalam pembelajaran matematika, semua siswa menggunakan pendekatan yang sama untuk menemukan suatu solusi tunggal dari masalah yang diberikan. Jawaban dan strategi yang tunggal terhadap suatu masalah kurang mendorong siswa untuk saling berkomunikasi karena masing-masing siswa akan lebih memfokuskan diri pada strategi mereka sendiri.

Sebaliknya, jika siswa menggunakan berbagai pendekatan yang berbeda dalam menemukan solusi, maka akan memungkinkan mereka untuk bertukar ide dan menjelaskan ide-ide mereka. Dalam situasi demikian, proses komunikasi akan terjadi dengan baik.

\section{Self Regulated Learning (Kemandirian Belajar)}

Self regulated learning merupakan salah satu konsep kunci dalam teori belajar konstruktivisme. Teori ini menganut visi atau wawasan siswa ideal sebagai pelajar yang memiliki kemampuan dan kemandirian belajar. Zimmerman dan Mautinez-pons (2005) menyatakan bahwa self regulated learning merukan konsep mengenai bagaimana seorang peserta didik menjadi pengatur bagi dirinya sendiri.

Berdasarkan perspektif sosial kognitif, peserta didik dapat dikatakan self regulated learner adalah peserta didik yang secara meta kognitif, motivasional, dan behavioral aktif dan turut serta dalam proses belajar mereka. Peserta didik tersebut dengan sendirinya memulai usaha belajar secara langsung untuk memperoleh pengetahuan dan keahlian yang ingin dimiliki tanpa tergantung pada guru, orang tua atau orang lain. Cobb (2003) menyatakan bahwa self regulated learning dipengaruhi oleh: (1) Self efficacy, yaitu penilaian individu terhadap kemampuan atau kompetensinya untuk melakukan suatu tugas, mencapai suatu

tujuan atau mengatasi hambatan dalam belajar; (2) Motivasi, sangat dibutuhkan peserta didik untuk melakukan strategi yang mempengaruhi proses belajar; (3) Tujuan merupakan kriteria yang digunakan peserta didik untuk memonitir kemajuan mereka dalam belajar kearah yang lebih spesifik.

Zimmerman (dalam Purdie, Hatti dam Douglas, (2000) melakukan penelitian tentang 10 kategori perilaku belajar sebagai self regulated learning sebagai berikut: (1) evaluasi 
terhadap kemajuan tugas (self evaluating); (2) mengatur materi pelajaran (organizing and transforming); (3) membuat rencana dan tujuan belajar (goal setting and planning); (4) mencari informasi (seeking information); (5) mencatat hal penting (keeping record and monitoring); (6) mengatur lingkungan belajar (enviromental structuring); (7) konsekuensi setelah mengerjakan tugas (self consequences); (8) mengulang dan mengingat (rehearsing and memorizing); (9) mencari bantuan sosial (seek social assistance; (10) meninjau kembali catatan, tugas atau tes dan buku teks (review record).

\section{Strategi PQ4R (Preview, Question, Read, Reflect, Recite, Review)}

Menurut paham konstruktivisme, pengetahuan dibangun secara aktif oleh siswa sendiri (Klopper dan Campagne [14]). Hal ini berarti siswa harus melakukan aktivitas belajar secara langsung yang memungkinkan mereka membangun pengetahuannya sendiri.

Salah satu strategi untuk membangun pemahaman dengan mengembangkan keterampilan metakognitif adalah PQ4R (Preview, Question, Read, Reflect, Recite, Review).

Langkah-langkah membaca dan memahami teks menggunakan strategi PQ4R menurut Slavin (1994) disajikan sebagai berikut:

1. Preview adalah aktivitas memeriksa atau meneliti atau mengindentifikasi seluruh teks. Pada aktivitas survey ini, guru perlu membantu dan memotivasi siswa untuk memeriksa atau meneliti seluruk struktur teks. Tujuannya agar siswa mengetahui panjangnya teks, judul bagian dan judul subbagian, istilah dan kata kunci, rangkuman dan sebagainya.

2. Question adalah aktivitas menyusun atau membuat pertanyaan yang relevan dengan teks. Pada langkah question ini, guru menyusun pertanyaan yang jelas, singkat dan relevan dengan bagian-bagian teks yang telah ditandai pada bagian pertama.

3. Read adalah aktivitas membaca teks secara aktif untuk mencari jawaban atas pertanyaanpertanyaan yang telah disusun. Guru perlu meminta siswa membaca secara aktif untukmencari jawaban atas pertanyaan yang telah disusun.

4. Reflect adalah aktivitas memikirkan contoh-contoh atau membuat bayangan materi ketika sedang membaca teks. Guru perlu memberikan contoh membuat elaborasi dan membuat hubungan apa yang sedang dibaca dengan apa yang sudah diketahui.

5. Recite adalah aktivitas menghafal setiap jawaban yang telah ditemukan. Pada langkah ini guru meminta siswa untuk menyebutkan lagi jawaban atas pertanyaan yang telah disusun.

6. Review adalah aktivitas meninjau ulang seluruh jawaban atas pertanyaan pada langkah kedua dan ketiga. Review yang efektif adalah dengan memasukkan lebih banyak materi atau informasi yang baru dalam memori jangka panjang. Membaca ulang adalah bentuk 
dari review, tetapi mencoba menjawab pertanyaaan tanpa mengacu pada kunci jawaban atau melihat buku adalah lebih baik.

Anderson (dalam woolfook,[18]) menyatakan bahwa langkah-langkah pada teknik membaca PQ4R dapat menjadikan siswa sadar terhadap organisasi teks, sehingga dapat mengatur dirinya sendiri untuk memperoleh informasi lebih mendalam dengan elaborasi yang lebih besar.

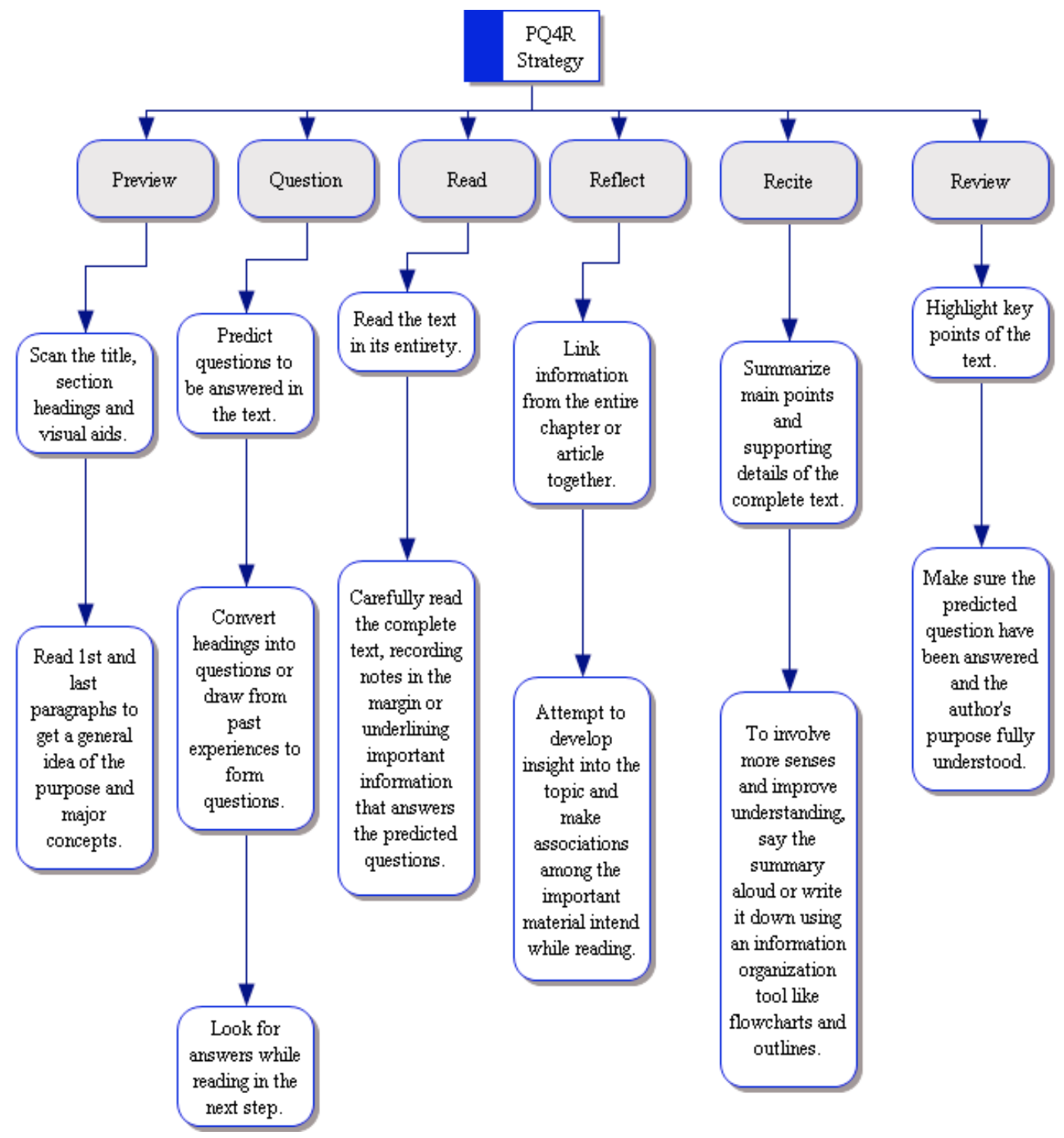

Gambar 1. Strategy PQ4R

\section{Komunikasi Matematika dan Self Regulated Learning dengan Strategi PQ4R dalam pembelajaran}

Belajar adalah suatu proses yang dilakukan seseorang untuk memperoleh perubahan tingkah laku yang baru secara keseluruhan". Perubahan ini meliputi perubahan sikap, 
keterampilan, pengetahuan, dan sebagai hasil pengalamannya sendiri dalam berinteraksi dengan lingkungannya.

Berdasarkan pendapat di atas belajar khususnya belajar matematika, dapat terjadi apabila siswa dan guru saling berinteraksi dan berkomunikasi mengenai materi matematika yang sedang dipelajari. Oleh karena itu, dalam pembelajaran matematika, kegiatan pengajaran diubah menjadi kegiatan pembelajaran.

Pembelajaran matematika lebih utama dibandingkan dengan pengajaran matematika, karena pembelajaran matematika mengoptimalkan keberadaan dan peran siswa sebagai pembelajar. Pembelajaran matematika diharapkan berakhir dengan sebuah pemahaman siswa yang komprehensif dan holistik tentang materi yang telah disajikan. Pemahaman yang dimaksud tidak sekedar memenuhi tuntutan pembelajaran matematika secara substantif saja, namun dapat memberikan manfaat kepada siswa, yaitu:

1. Lebih memahami keterkaitan antara satu topik matematika dengan topik matematika yang lainnya

2. Lebih menyadari akan penting dan strategisnya matematika bagi bidang lain

3. Lebih memahami peranan matematika dalam kehidupan manusia

4. Lebih mampu berfikir logis, kritis dan sistematis

5. Lebih kreatif dan inovatif dalam mencari solusi pemecahan sebuah masalah

6. Lebih peduli pada lingkungan sekitarnya.

Komunikasi matematika terbukti sangat perlu dikembangkan pada siswa. Kemampuan dasar dalam matematika untuk memberi alasan dan menyelesaikan masalah. Komunikasi matematika akan lebih efektif jika menggunakan metode diskusi. Kolaborasi sesama teman dalam suatu kelompok belajar akan mengembangkan kemampuan komunikasi matematika sehingga siswa saling dapat bertukar informasi satu sama lain. hal ini akan menolong siswa yang merasa kesulitan mengingat materi tertentu untuk menyelesaikan masalah dengan demikan dapat terbantu oleh temannya.

Selain itu melalui diskusi, interaksi dan komunikasi yang terjadi sesama kawan mampu memberi pengaruh yang positif kepada siswa karena mereka merasakan manfaatnya dengan suasana yang saling menguntungkan, saling memiliki, saling menerima, saling menghargai dan saling menghargai satu sama lain. dengan demikian juga akan menumbuhkan aktivitas sosial antara siswa dan mengembangkan kemampuan self regulated learning.

Pengaruh self regulated learning terhadap pembelajaran sangat besar. Oleh karena sifat self regulated learning yang bersifat dinamis (tidak lepas dari perubahan) memungkinkan siswa untuk meningkatkan dan memperbaiki kemandirian belajarnya. Self regulated learning 
juga memungkinkan siswa memperoleh kesempatan untuk mengembangkan ide-ide melalui aktivitas belajar atau didalam komunitas belajar. Dalam pembelajaran yang menerapkan PQ4R juga dapat mengelaborasi berbagai pengalaman belajar. Pengalaman mengelaborasi ide-ide matematika berperan sebagai stimulus awal siswa untuk memdorong dalam mengkonstruksi model matematika. Kemampuan mengelaborasi yang lebih luas juga akan membentuk siswa kreatif dalam menyelesaikan masalah matematika.

\section{Penelitian yang Relevan}

Hasil sejalan dengan penelitian Dr. Darmiany, M.Pd (2012) yang mengambil mahasiswa sebagai sampel Self Regulated Learning menemukan bahwa:

1. Apabila Self Regulated Learning telah dimiliki mahasiswa secara personal mahasiswa dapat meningkatkan kemampuan kognitif dan motivasi, secara proaktif dapat memilih lingkungan belajar yang menguntungkan untuk mencapai tujuan belajar.

2. Mahasiswa tertolong untuk berpikir kreatif sehingga pemahaman matematika mahasiswa pun meningkat.

Selanjutnya Slater, et al ( dalam Edy Tandililing 2011) menemukan bahwa dengan menerapkan PQ4R siswa mendapatkan peluang lebih untuk melakukan sesuatu, berpikir, memainkan peran yan aktif, melakukan sesuatu yang orisinal dan menarik kesimpulan sesuai dengan caranya sendiri dan dapat meningkatkan pemahaman siswa pada berbagai level sekolah.

Selain itu berdasarkan penelitian Edi Tandililing (2011) menemukan bahwa pembelajaran matematika dengan kemampuan komunikasi dan Self Regulated Learning dengan strategi PQ4R menunjukkan secara signifikan lebih baik dengan siswa SMA dengan pembelajaran biasa. Strategi PQ4R sebesar 0,47 lebih atas dari 0,27. Ini menunjukkan bahwa strategi PQ4R dapat meningkatkan kemampuan matematis siswa.

Dengan PQ4R siswa tidak sekedar menghafal dan mengulang tanpa pemahaman makna, tetapi juga melibatkan siswa berpikir dan mencari pemahaman terhadap informasi yang sedang dipelajari. Dengan demikian dapat disimpulakan bahwa kemampuan komunikasi siswa dan self regulated learning dengan strategi $\mathrm{PQ} 4 \mathrm{R}$ dapat meningkatkan pemahaman matematika siswa. 


\section{Simpulan dan Saran}

Berdasarkan pembahasan penelitian, maka dapat dikemukakan kesimpulan sebagai berikut:

1. Komunikasi matematika siswa dapat membangun pemahaman melalui proses interaksi antara guru, siswa dan media selama proses pembelajaran.

2. Siswa yang ideal adalah siswa yang memiliki pemahaman dan kemandirian belajar ( Self Regulated Learning) dimana siswa dapat mengatur bagi dirinya sendiri.

3. Melalui penerapan strategi PQ4R menungkinkan siswa membangun pengetahuannya sendiri.

Saran dari pembahasan di atas sebagai berikut:

1. Pendidik dapat menggunakan strategi PQ4R selama proses pembelajaran matematika di kelas

2. Guna pengembangan keilmuan lebih lanjut, penelitian mengenai komunikasi matematika dan self-regulated learning dapat dikembangkan dengan metode dan strategi belajar yang bervariasi.

\section{Referensi}

Arends, Richard. (1997). Classroom Instructional Management. New York: Mc Grw-Hill Company

Baroody, A.J. (1993). Problem Solving, Reasioning, and Communicating, K-8 Helping Children Think Matematically. New York: Mc Millan Publishing Company

Boekarts, M., Pintrich., \& Zeidner, M. (2000). Hand Book of Self Relation. California: Academic Press.

Cobb, P., Yackel, E., \& Wood,T (2003). A Constructivis Alternative the Representatianal view of mind in Mathematics Education. Journal for Reach in Mathematics Educations, 23(1), 2-33

Darmiany, (2012). Self Regulated Learning [SRL] Riset dan Aplikasi, Mataram, Arga Puji Press.

Edi Tandililing, 2011. The enhancement of Mathematical Communication and self Regulated Learning of high school students through PQ4R Strategy Accompanied by refutation text reading, Paper has been presented at international seminar and fourt national conference on mathematics education. Yogyakarta State University.

Hiebert \& Carpenter, (1992). Learning and Teaching with understanding in Grows. Handbook of Research on Mathematics Learning and Teaching, 65-67. New York: McMillan.

Kerlin, BA. (1992). Cognitive Engagement Style, Self Regulated Learning and Cooperative Learning (Online). http://kerlins.net/bobbi/research/myreasearch/srl .html. diakses 18 September 2018 
Kloppel and Campagne, Communication in Mathematics, Master Action Research Project, St. Xavier University\&iIRI/Skylight.

Slavin, R.E.(1994). The PQ4R Method was Development. Education Psicology: Theory and Practice. Boston: Allyn \& Bacon.

Slavin, R.E. (2000). Educational Psychology: Theory and Practice. Boston: Allyn \& Bacon

Sumarmo, U. (2000). Pengembangan Model Pembelajaran Matematika untuk Meningkatkan Kemampuan Intelektual Tingkat Tinggi Siswa Sekolah Dasar, Laporan Penelitian FMIPA UPI.

Thomas \& Robinson,(1999), Teaching Text Structure to Improve Reading and Writing, Science Education, 26, 130-137.

Zimmerman, B.J. (2000). Teories of Self Regulated Learning and Academic Achivement: An Overview and Analysis. Self Regelated Learning and Academic Achivement: Theoritical Perspective. $2^{\text {nd }}$ Edition. Lawrece Erlbaum Associates Inc. 10 Industrial Avanue, Mahwah, NJ 07430 